https://doi.org/10.19195/0524-4544.329.29

\author{
KATARZYNA MARAK
}

ORCID: 0000-0002-3402-5770

Uniwersytet Ekonomiczny we Wrocławiu

katarzyna.marak@ue.wroc.pl

\title{
Transpozycja konsumenckich dyrektyw maksymalnych na przykładzie dyrektywy turystycznej 2015/2302 do polskiego porządku prawnego
}

\begin{abstract}
Abstrakt: Dyrektywy konsumenckie licznie uchwalane w latach osiemdziesiątych i dziewięćdziesiątych XX wieku były oparte na metodzie minimalnej harmonizacji. Nie przyniosło to jednak spodziewanych rezultatów w zakresie zadawalającego zbliżenia systemów prawnych państw członkowskich i na początku XXI wieku prawodawca unijny zrezygnował z harmonizacji minimalnej na rzecz harmonizacji zupełnej (maksymalnej). Na gruncie usług turystycznych obowiązywała dyrektywa z 1990 roku w sprawie zorganizowanych wakacji, wycieczek i podróży, oparta na najniższym wspólnym mianowniku. Obecnie została ona zastąpiona dyrektywą z 2015 roku w sprawie imprez turystycznych i powiązanych usług turystycznych, wpisującą się w trend dyrektyw maksymalnych. W artykule poddano analizie i ocenie skuteczność zastosowania metody pełnej harmonizacji jako sposobu realizacji celów i założeń dyrektyw konsumenckich na przykładzie dyrektywy turystycznej z 2015 roku. W założeniu harmonizacja maksymalna powinna wydatnie przyczyniać się do urzeczywistniania idei wspólnego rynku, ułatwiać przedsiębiorcom świadczenie usług w sposób transgraniczny i jednocześnie zapewniać wysoki i jednolity poziom ochrony konsumentów. Jednakże analiza dyrektyw konsumenckich w kontekście ich transpozycji prowadzi do wniosku, że harmonizacja maksymalna raczej nie spełni pokładanych w niej oczekiwań. Nie doprowadzi do pełnego zbliżenia prawa w obszarach objętych zakresami dyrektyw; odrębności będą nadal występować i w dalszym ciągu będą zniechęcać konsumentów do usług transgranicznych. Natomiast negatywne konsekwencje transpozycji dyrektyw maksymalnych uwidoczniają się w postaci znacznej ingerencji w porządki prawne państw członkowskich i mogącym wystąpić negatywnym wpływem na stabilność krajowych systemów prawnych.
\end{abstract}

Słowa kluczowe: ochrona konsumenta, harmonizacja maksymalna, dyrektywa turystyczna, umowa o imprezę turystyczną, dyrektywy konsumenckie. 


\section{Wstęp}

Ustawodawca powinien podążać za zmianami zachodzącymi we współczesnym świecie, a przynajmniej powinien się starać nadawać nowym zjawiskom właściwe ramy legislacyjne, ale tylko w dziedzinach, które wymagają takiej regulacji, powstrzymując się przy tym od nadmiernej regulacji tych obszarów ludzkiej aktywności, które dobrze funkcjonują bez ingerencji ustawodawcy — jurydyzacja życia jest bowiem zjawiskiem niepożądanym.

Prawodawstwo mające za przedmiot ochronę konsumenta powinno umiejętnie nadążać za zmianami zachodzącymi w obszarach codziennego funkcjonowania konsumenta. W dziedzinie turystyki, w ciągu minionego ćwierćwiecza, zaszły ogromne zmiany na rynku, związane zwłaszcza z rozwojem Internetu i tanich linii lotniczych, co spowodowało potrzebę rewizji podejścia do kwestii ochrony prawnej podróżnych. Trudności związane z regulacjami konsumenckimi dotyczą ich przedmiotu i zakresu, jak również metody transpozycji do krajowych porządków prawnych. $Z$ biegiem czasu zmieniła się również technika legislacyjna, którą posługuje się prawodawca unijny.

Wyjaśnienia wymaga, iż pod pojęciem dyrektyw konsumenckich w niniejszym opracowaniu rozumie się zbiór dyrektyw unijnych ukierunkowanych na ochronę interesów konsumenta, przedmiot zainteresowania stanowią zaś przepisy dyrektyw konsumenckich o charakterze prywatnoprawnym, w szczególności dotyczących prawa umów. W artykule poddano analizie i ocenie skuteczność zastosowania metody harmonizacji maksymalnej jako sposobu na urzeczywistnienie celów i założeń dyrektyw konsumenckich na przykładzie dyrektywy turystycznej.

\section{Dyrektywy konsumenckie i poziom ich harmonizacji — przeszłość i teraźniejszość}

Dyrektywy licznie uchwalane w latach osiemdziesiątych i dziewięćdziesiątych XX wieku były oparte na metodzie minimalnej harmonizacji. Wśród nich tytułem przykładu można wskazać na następujące: dyrektywa Rady 85/577/EWG z dnia 20 grudnia 1985 roku w sprawie ochrony konsumentów w odniesieniu do umów zawartych poza lokalem przedsiębiorstwa ${ }^{1}$, dyrektywa Rady 90/314/ EWG z dnia 13 czerwca 1990 roku w sprawie zorganizowanych podróży, wakacji i wycieczek², dyrektywa Rady 93/13/EWG z dnia 5 kwietnia 1993 roku w sprawie nieuczciwych warunków w umowach konsumenckich ${ }^{3}$, dyrektywa 94/47/WE

\footnotetext{
1 Dz.U. UE L 372/31 z dnia 31 grudnia 1985 roku (uchylona przez dyrektywę 2011/83/UE).

2 Dz.U. UE L 158/59 z dnia 23 czerwca 1990 roku (uchylona przez dyrektywę 2015/2302 UE).

3 Dz.U. UE L 95/29 z dnia 21 kwietnia 1993 roku.
} 
Parlamentu Europejskiego i Rady z dnia 26 października 1994 roku w sprawie ochrony nabywców w odniesieniu do niektórych aspektów umów odnoszących się do nabywania praw do korzystania $\mathrm{z}$ nieruchomości w oznaczonym czasie (tak zwany timesharing) ${ }^{4}$, dyrektywa 97/7/WE Parlamentu Europejskiego i Rady z dnia 20 maja 1997 roku w sprawie ochrony konsumentów w przypadku umów zawieranych na odległość ${ }^{5}$, dyrektywa 1999/44/WE Parlamentu Europejskiego i Rady z dnia 25 maja 1999 roku w sprawie niektórych aspektów sprzedaży towarów konsumpcyjnych i związanych z tym gwarancji ${ }^{6}$.

O harmonizacji minimalnej świadczy wprost posługiwanie się przez prawodawcę unijnego sformułowaniem rodzaju: ,w celu zapewnienia wyższego stopnia ochrony konsumenta, państwa członkowskie mogą przyjąć lub utrzymać bardziej rygorystyczne przepisy prawne zgodne $\mathrm{z}$ Traktatem w dziedzinie objętej dyrektywą"7. Przyjmowanie wyższych standardów w przepisach krajowych i wychodzenie ponad tak zwany najniższy wspólny mianownik nie może zatem prowadzić do naruszenia zobowiązań wynikających z Traktatu o funkcjonowaniu Unii Europejskiej.

Pierwszą i w tamtym czasie odosobnioną dyrektywą opartą na metodzie maksymalnej harmonizacji była dyrektywa 85/374/EWG z dnia 25 lipca 1985 roku o odpowiedzialności za produkt ${ }^{8}$. Następnie dopiero dyrektywa 2002/65/WE Parlamentu Europejskiego i Rady z dnia 23 września 2002 roku dotycząca sprzedaży konsumentom usług finansowych na odległość oraz zmieniająca dyrektywę Rady 90/619/EWG oraz dyrektywy 97/7/WE i 98/27/WE ${ }^{9}$ również oparta została na metodzie pełnej harmonizacji.

Harmonizacja maksymalna, począwszy od roku 2005, stała się standardem dyrektyw konsumenckich. Można wskazać na następujące: dyrektywa 2005/29/ WE Parlamentu Europejskiego i Rady z dnia 11 maja 2005 roku o nieuczciwych praktykach handlowych ${ }^{10}$, dyrektywa Parlamentu Europejskiego i Rady 2008/122/WE z dnia 14 stycznia 2009 roku w sprawie ochrony konsumentów w odniesieniu do niektórych aspektów umów timeshare, umów o długoterminowe produkty wakacyjne, umów odsprzedaży oraz wymiany ${ }^{11}$, dyrektywa 2008/48/ WE Parlamentu Europejskiego i Rady z dnia 23 kwietnia 2008 roku w sprawie umów o kredyt konsumencki oraz uchylająca dyrektywę Rady 87/102/EWG ${ }^{12}$, dyrektywa Parlamentu Europejskiego i Rady 2011/83/UE z dnia 25 październi-

4 Dz.U. UE L 280/83 z dnia 29 października 1994 roku (uchylona dyrektywą 2008/122 WE).

5 Dz.U. UE L 144/19 z dnia 4 czerwca 1997 roku (uchylona dyrektywą 2011/83/UE).

6 Dz.U. UE L 171/12 z dnia 7 lipca 1999 roku.

7 Zob. na przykład art. 8 dyrektywy w sprawie nieuczciwych warunków w umowach konsumenckich.

${ }^{8}$ Dz.U. UE L 210/29 z dnia 7 sierpnia 1985 roku.

9 Dz.U. UE L 271/16 z dnia 9 października 2002 roku.

10 Dz.U. UE L 149/22 z dnia 11 czerwca 2005 roku.

11 Dz.U. UE L 33/10 z dnia 3 lutego 2009 roku.

12 Dz.U. UE L 133/66 z dnia 22 maja 2008 roku. 
ka 2011 roku w sprawie praw konsumentów, zmieniająca dyrektywę Rady 93/13/ EWG i dyrektywę 1999/44/WE Parlamentu Europejskiego i Rady oraz uchylająca dyrektywę Rady 85/577/EWG i dyrektywę 97/7/WE Parlamentu Europejskiego i Rady ${ }^{13}$, dyrektywa Parlamentu Europejskiego i Rady (UE) 2015/2302 z dnia 25 listopada 2015 roku w sprawie imprez turystycznych i powiązanych usług turystycznych zmieniającej rozporządzenie (WE) nr 2006/2004 i dyrektywę Parlamentu Europejskiego i Rady 2011/83/UE oraz uchylającej dyrektywę Rady 90/314/EWG. Unormowanie to zastąpiło obowiązującą przez wiele lat dyrektywę Rady 90/314/EWG z dnia 13 czerwca 1990 roku w sprawie zorganizowanych podróży, wakacji i wycieczek ${ }^{14}$.

$\mathrm{Na}$ harmonizację maksymalną wskazuje wprost posługiwanie się przez prawodawcę unijnego sformułowaniem rodzaju:

państwa członkowskie nie mogą utrzymywać ani wprowadzać do swojego prawa krajowego przepisów odbiegających od tych, które zostały ustanowione w niniejszej dyrektywie, w tym również przepisów surowszych lub łagodniejszych w celu zapewnienia innego poziomu ochrony konsumentów, chyba że niniejsza dyrektywa stanowi inaczej ${ }^{15}$.

Obecnie do rzadkości należy wydawanie dyrektyw opartych na metodzie minimalnej harmonizacji.

\section{Harmonizacja minimalna i maksymalna jako metody zbliżania ustawodawstw państw członkowskich}

Poszczególne metody harmonizacji pozostawiają państwom członkowskim różny zakres swobody implementacyjnej. Metoda harmonizacji, na której została oparta dyrektywa, może zakazywać bądź dozwalać przyjmowania — w zakresie objętym dyrektywą — krajowych rozwiązań prawnych, odmiennych od postanowień dyrektywy. Najmniej swobody pozostawia harmonizacja zupełna a najwięcej zaś - minimalna. Decyzja o wyborze metody harmonizacji dla konkretnej dyrektywy zależy od wielu czynników prawnych i politycznych. Znaczenie mają następujące kwestie: cel dyrektywy, przedmiot i charakter omawianej materii, traktatowa podstawa prawna, akceptowalny dla państw członkowskich stopień (intensywność) ingerencji w systemy krajowe w danej dziedzinie, a tym samym możliwość osiągnięcia jednomyślności w procesie prawodawczym ${ }^{16}$.

13 Dz.U. UE L 304/64 z dnia 22 listopada 2011 roku.

14 Dz.U. UE L 326/1 z dnia 11 grudnia 2015 roku, dalej: dyrektywa turystyczna.

15 Zob. na przykład art. 4 dyrektywy w sprawie praw konsumentów Poziom harmonizacji.

16 A. Kunkiel-Kryńska, Metody harmonizacji prawa konsumenckiego w Unii Europejskiej i ich wpływ na procesy implementacyjne w państwach członkowskich, Warszawa 2013, s. 62-63. 
W kwestii podstaw prawnych dyrektyw należy zauważyć, że kompetencje UE i jej organów w zakresie harmonizacji prawa wynikają z art. 114-118 TFUE ${ }^{17}$ (rozdział 3. Zbliżanie ustawodawstw). Zgodnie $\mathrm{z}$ art. 26 ust. 1 TFUE Unia przyjmuje środki w celu ustanowienia lub zapewnienia funkcjonowania rynku wewnętrznego zgodnie z odpowiednimi postanowieniami traktatów. Kluczową rolę odgrywają przepisy stanowiące podstawę wydania dyrektywy. O ile art. 114 czy art. 169 TFUE dają możliwość przyjmowania regulacji odmiennych od treści dyrektywy, o tyle art. 115 już takiej opcji nie przewiduje ${ }^{18}$. Na kształt przepisów unijnych może zatem wpływać nie tylko rzeczywisty cel ich wydania i merytoryczne czynniki decydujące o tym, jaki jest pożądany kierunek regulacji określonej dziedziny spraw, ale także kształt podstawy traktatowej, na której przepisy te są oparte, czyli zakres kompetencji do regulowania danej sfery ${ }^{19}$. Zgodnie z art. 288 TFUE dyrektywa wiąże państwo członkowskie w odniesieniu do rezultatu, który ma być osiągnięty, pozostawia jednak organom krajowym swobodę wyboru formy i środków.

W przeszłości do dyrektyw konsumenckich stosowano metodę minimalnej harmonizacji, zgodnie z którą dyrektywa określa minimalne standardy regulacji, a państwa członkowskie mogą ustanowić w prawie krajowym przepisy bardziej restrykcyjne od zawartych w dyrektywie. Przyjęcie rozwiązań prawnych według tak zwanego najniższego wspólnego mianownika powodowało, że poszczególne państwa członkowskie mogły utrzymać lub podwyższyć te standardy ${ }^{20}$.

Analiza dokumentów programowych instytucji unijnych prowadzi do wniosku, że metoda harmonizacji minimalnej była oceniana negatywnie. Głównym zarzutem przeciwko stosowaniu tej metody było doprowadzenie do fragmentarycznie i (wtórnie) zróżnicowanych przepisów prawnych w państwach członkowskich, co wywiera niekorzystny wpływ na wewnątrzunijną wymianę handlową ${ }^{21}$.

Od kilkunastu lat zasadę stanowi opieranie dyrektyw konsumenckich na metodzie harmonizacji maksymalnej (pełnej, zupełnej, całkowitej) ${ }^{22}$.

17 Traktat o funkcjonowaniu Unii Europejskiej (wersja skonsolidowana), Dz.U. UE C 326 z dnia 26 października 2012, dalej: TFUE.

18 M. Jagielska, Ewolucja ochrony konsumenta w prawie kolizyjnym UE w zakresie zobowiazań umownych, Warszawa 2010, s. 123.

19 P. Machnikowski, Harmonizacja maksymalna jako metoda zbliżania prawa zobowiazań w UE na przyktadzie odpowiedzialności za produkt, „Studia Prawa Prywatnego” 2017, nr 35, s. 8.

20 Zob. na przykład J. Maliszewska-Nienartowicz, Ewolucja ochrony konsumenta w europejskim prawie wspólnotowym, Toruń 2004, s. 154-155; A. Cieśliński, Wspólnotowe prawo gospodarcze, Warszawa 2003, s. 395.

21 A. Kunkiel-Kryńska, op. cit., s. 290.

22 Szerzej na temat harmonizacji maksymalnej w obszarze prawa ochrony konsumentów A. Kunkiel-Kryńska, op. cit., passim; B. Gnela, Umowa konsumencka w polskim prawie cywilnym i prywatnym międzynarodowym, Warszawa 2013, s. 78 n.; R. Stefanicki, Tendencje zmian w europejskiej strategii ochrony konsumenta, „Kwartalnik Prawa Prywatnego” 18, 2008, z. 3, s. 687 n., idem, Koncepcja petnej harmonizacji prawa ochrony konsumenta (na przyktadzie dyrektywy o nieuczciwych praktykach handlowych), PiP 2011, z. 6, s. 51 n.; M. Kępiński, Harmonizacja maksymalna - nowe wyznanie dla ustawodawcy, [w:] Aktualne tendencje w prawie konsumenckim, red. 
Harmonizacja maksymalna przewiduje całkowite uregulowanie przez państwo członkowskie materii prawnej objętej zakresem dyrektywy, bez możliwości wykraczania poza przewidziany w niej standard ochrony. Dyrektywy takie zakazują państwom członkowskim przyjmowania i utrzymywania rozwiązań odbiegających w stosunku do przepisów dyrektywy zarówno na niekorzyść, jak i na korzyść konsumenta. Harmonizacja całkowita charakteryzuje się szerokim zakresem regulacji i najwyższym stopniem natężenia zbliżania norm. W literaturze przedmiotu podkreśla się, że harmonizacja pełna prowadzi do podobnych rezultatów jak unifikacja. Podkreśla się wręcz, że dyrektywy tego rodzaju transformuje w rozporządzenia ${ }^{23}$. Dyrektywy te mogą być postrzegane jako quasi-rozporządzenia. Dyrektywa zupełna może jednak zawierać postanowienia łagodzące jej rygoryzm, może przewidywać tak zwaną możliwość derogacji ${ }^{24}$.

\section{Transpozycja dyrektywy turystycznej}

W art. 1 dyrektywy turystycznej podkreślono, iż jej celem jest przyczynienie się do prawidłowego funkcjonowania rynku wewnętrznego i osiągnięcia wysokiego i jak najbardziej jednolitego poziomu ochrony konsumentów odnośnie do przepisów ustawowych, wykonawczych i administracyjnych państw członkowskich, w odniesieniu do umów o imprezę turystyczną i powiązane usługi turystyczne zawieranych między podróżnymi a przedsiębiorcami. Celem dyrektywy jest również dostosowanie zakresu ochrony do zmian, jakie zaszły na rynku podróży (między innymi rozwój tanich linii lotniczych i internetu) oraz zwiększenie przejrzystości i pewności prawa dla podróżnych i przedsiębiorców ${ }^{25}$.

W świetle treści zawartych $\mathrm{w}$ art. 1 dyrektywy, można zatem wskazać na następujące dążenia prawodawcy unijnego - po pierwsze, jest to przyczynienie się do prawidłowego funkcjonowania rynku wewnętrznego, a więc zapewnienia swobody przepływu towarów i usług oraz swobody przedsiębiorczości, a po wtóre, osiągnięcie wysokiego oraz jednolitego poziomu ochrony konsumentów.

Nie sposób nie dostrzec tego, że harmonizacja prawa UE jest związana z realizacją rynku wewnętrznego, a ochrona konsumenta stanowi tylko środek do urzeczywistniania idei wspólnego rynku. Przepis art. 26 ust. 2 zawiera le-

R. Stefanicki, Wrocław 2010, s. 33 n.; F. Grzegorczyk, Jednolity rynek europejski jako determinant rozwoju prawa konsumenckiego w Unii Europejskiej, KPP 19, 2010, z. 4, s. 905 n.; J. Gospodarek, Implementacja nowej dyrektywy turystycznej z $2015 \mathrm{r}$. do systemu prawa polskiego, [w:] Prawo konsumenckie w Polsce oraz innych państwach UE. Zagadnienia wybrane, red. B. Gnela et al., Warszawa 2019, s. 99 n.

23 A.P.R. Café, Package Travel Directive: Contractual parties and level of harmonization, [w:] The New Package Travel Directive, red. V. Franceschelli, F. Morandi, C. Torres, Lisboa 2017, s. 348.

24 Zob. A. Kunkiel-Kryńska, op. cit., s. 291.

25 Por. preambułę dyrektywy, zwłaszcza jej motywy 1-6. 
galną definicję rynku wewnętrznego, zgodnie z którą jest to obszar bez granic wewnętrznych, w którym zapewniony jest swobodny przepływ towarów, osób, usług i kapitału. W motywie 5 preambuły dyrektywy podkreślono, że ujednolicenie praw i obowiązków wynikających z umów dotyczących imprez turystycznych oraz powiązanych usług turystycznych jest niezbędne w celu stworzenia prawdziwego wewnętrznego rynku konsumenckiego w tym obszarze, przy jednoczesnym zachowaniu właściwej równowagi pomiędzy wysokim poziomem ochrony konsumentów a konkurencyjnością przedsiębiorstw.

Dodatkowo rozbieżności w przepisach chroniących podróżnych w poszczególnych państwach członkowskich zniechęcają ich do zakupu imprez turystycznych i powiązanych usług turystycznych w innym państwie członkowskim. Podobnie zniechęcają one organizatorów i sprzedawców detalicznych do sprzedaży takich usług w innym państwie członkowskim. Transgraniczny potencjał rynku zorganizowanych podróży w Unii nie jest obecnie w pełni wykorzystany ${ }^{26}$. Uzasadnieniem szerokiego stosowania metody harmonizacji maksymalnej są zatem argumenty odwołujące się do występowania przeszkód w handlu transgranicznym, polegających na różnicach w poziomie ochrony konsumenta i będących ich korelatami w obowiązkach przedsiębiorców.

Prawodawca unijny z jednej strony podkreśla znaczenie jednolitości regulacji we wszystkich państwach członkowskich, a z drugiej — dopuszcza liczne wyjątki od tej jednolitości. Wyjątki te mają różny charakter.

Zgodnie z motywem 21 preambuły państwa członkowskie powinny, zgodnie z prawem Unii, zachować swoje kompetencje w zakresie stosowania przepisów niniejszej dyrektywy do dziedzin nieobjętych zakresem jej stosowania. Tytułem przykładu podano obszary i podmioty, na które można rozciągnąć regulacje dyrektywy, na przykład umów o pojedyncze usługi turystyczne, jak wynajem domów wakacyjnych lub imprez turystycznych i powiązanych usług turystycznych oferowanych, wyłącznie sporadycznie, na zasadach niekomercyjnych, ograniczonej grupie podróżnych, jak choćby pielgrzymki organizowane przez kościoły dla swoich wiernych, lub imprez turystycznych i powiązanych usług turystycznych obejmujących okres krótszy niż 24 godziny i nieobejmujących zakwaterowania.

Kolejne, podobnego rodzaju, odstępstwo znajdujemy w z art. 13 ust. 1 akapit 2, w którym to prawodawca unijny przewiduje swobodę dla ustawodawców krajowych odnoszącą się do możliwości wskazania podmiotu odpowiedzialnego za realizację usług turystycznych objętych umową. Nie ulega wątpliwości, że organizatorzy imprez turystycznych odpowiadają za właściwą realizację imprezy. Dodatkowo przepisy krajowe mogą przewidywać rozszerzenie katalogu podmiotów odpowiedzialnych i objęcie nimi także sprzedawców detalicznych, czyli na przykład pośredników turystycznych czy agentów turystycznych ${ }^{27}$.

26 Zob. motyw 6 preambuły dyrektywy.

27 Na gruncie poprzednio obowiązującej ustawy z 1997 roku o usługach turystycznych wyróżniano u nas kategorię pośredników turystycznych i ponosili oni w pewnych sytuacjach odpowiedzial- 
Jeszcze inna swoboda implementacyjna wynika z art. 12 ust. 5 dyrektywy i dotyczy umów zawieranych poza lokalem przedsiębiorstwa. W stosunku do takich kontraktów państwa członkowskie mogą zdecydować, że podróżnemu będzie przysługiwać prawo do odstąpienia od umowy w ciągu 14 dni bez podawania przyczyn. Zawieranie umów przez internet jest obecnie powszechne - powyższe postanowienia mają zatem ogromne znaczenie praktyczne. Jeżeli podróżny chciałby dokonać zakupu imprezy pakietowej w zagranicznym biurze podróży, wówczas naturalnym sposobem będzie wyszukiwanie ofert za pośrednictwem internetu i dokonanie zakupu poza lokalem przedsiębiorstwa. Jednak w takiej sytuacji podróżny nie będzie miał pewności co to tego, czy przysługuje mu prawo do odstąpienia od umowy w ciągu 14 dni. Może nabyć imprezę turystyczną w przekonaniu, że będzie mógł się rozmyślić w rzeczonym czternastodniowym terminie, zwłaszcza gdy jego rodzime prawo przewiduje takie uprawnienie. Brak jednolitości regulacji $\mathrm{w}$ kwestiach tak pierwszoplanowych, jak zakup przez internet, może wręcz wprowadzać konsumentów w błąd; skutkuje brakiem pewności prawa i w żaden sposób nie zapewnia wysokiego poziomu ochrony konsumentom.

Dyrektywy konsumenckie oparte na metodzie harmonizacji maksymalnej posługują się zwrotami niedookreślonymi i pojęciami nieostrymi, w tym konstrukcją klauzul generalnych. Niedookreśloność dotyczy znaczenia zwrotów (nieokreślona, niewyraźna treść), natomiast nieostrość dotyczy ich zakresu ${ }^{28}$. W obszarze ochrony konsumentów niedookreśloność i nieostrość mogą być stosowane zamiennie, ponieważ analizowane kwestie interpretacyjne dla obu kategorii są takie same ${ }^{29}$. Posługiwanie się zwrotami niedookreślonymi (pojęciami nieostrymi) i klauzulami generalnymi stanowi jeden ze środków techniki prawodawczej. Obecność takich pojęć w tekście prawnym jest efektem świadomego działania prawodawcy podjętego $\mathrm{w}$ celu preferowania elastyczności rozwiązania i zapewnienia luzu decyzyjnego ${ }^{30}$.

Przepisy, które w sposób zamierzony określone są nieprecyzyjnie, wskazują na potrzebę uwzględniania kryteriów pozaprawnych przy dokonywaniu kwalifikacji pewnych stanów, ocenie działań lub zaniechań czy też podejmowaniu decyzji na ich podstawie. Podstawowa ich zaleta polega na tym, że dzięki nim prawo jest bardziej elastyczne, może reagować na zmiany zachodzące we współczesnym społeczeństwie związane chociażby z postępem technicznym i rozwojem nowoczesnych technologii. Z kolei za ich wadę uważa się ich ogólnikowość, ponieważ może ona prowadzić do nadużywania swobody podczas ich interpretacji i stosowania ${ }^{31}$.

ność za realizację imprezy turystycznej. Obecnie nasz ustawodawca zrezygnował z tej możliwości i odpowiedzialność za realizację umowy pakietowej ponoszą jedynie organizatorzy turystyki.

28 Zob. M. Zieliński, Wyktadnia prawa. Zasady. Reguty. Wskazówki, Warszawa 2002, s. 163 n.

29 A. Kunkiel-Kryńska, op. cit., s. 327.

${ }^{30}$ E. Łętowska, Interpretacja a subsumpcja zwrotów niedookreślonych i nieostrych, PiP 2011, nr 7-8, s. 17 n.

31 Zob. więcej na temat pojęć nieostrych w dyrektywie turystycznej K. Marak, Harmonizacja maksymalna projektowanej dyrektywy turystycznej i możliwe odstępstwa od tak wyznaczonego 
Dyrektywa turystyczna posługuje się pojęciami niedookreślonymi, jak naprzykład nieuniknione i nadzwyczajne okoliczności, skuteczna ochrona na wypadek niewypłacalności, znalezienie się podróżnego w trudnej sytuacji, które zobowiązuje organizatora do udzielenia mu pomocy.

Pojęcie „nieuniknionych i nadzwyczajnych okoliczności” nie występowało na gruncie poprzednio obowiązującej dyrektywy turystycznej z 1990 roku — nie ma więc ugruntowanego w prawie unijnym znaczenia. W wypadku wystąpienia nieuniknionych i nadzwyczajnych okoliczności przyznaje się podróżnemu prawo do rozwiązania umowy i rezygnacji z imprezy turystycznej przed jej rozpoczęciem bez ponoszenia jakichkolwiek opłat (art. 12 ust. 2). Chodzi tu o nieuniknione i nadzwyczajne okoliczności występujące w miejscu docelowym lub jego najbliższym sąsiedztwie, które to okoliczności w znacznym stopniu wpływają na imprezę turystyczną lub które w znacznym stopniu wpływają na przewóz pasażerów do miejsca docelowego. Jak zatem należy rozumieć to pojęcie? Jedynie w preambule dyrektywy zawarto wyjaśnienie, że

może to obejmować na przykład działania wojenne, inne poważne problemy związane z bezpieczeństwem, takie jak terroryzm, istotne zagrożenia dla zdrowia ludzkiego, takie jak wybuch epidemii poważnej choroby w docelowym miejscu podróży, lub katastrofy naturalne, takie jak powodzie lub trzęsienia ziemi, lub warunki pogodowe uniemożliwiające bezpieczną podróż do miejsca docelowego uzgodnionego w umowie.

Nasz ustawodawca krajowy nie podjął próby określenia tych sytuacji, których wystąpienie należałoby kwalifikować jako „nieuniknione i nadzwyczajne okoliczności”. Pozostawił te kwestie zmaganiom konsumentów z przedsiębiorcami turystycznymi. Pojęcie to podlegać będzie zatem wyjaśnieniu w drodze wykładni. Ostatecznie ustalenie, co kryje się pod takim pojęciem, należeć będzie do organów stosujących prawo.

Można zadać pytanie o efekt, jaki osiągnie prawodawca przez użycie tak wielu zwrotów niedookreślonych.

$Z$ jednej strony, dyrektywom zupełnym towarzyszy dążenie do ujednolicenia standardów ochronnych we wszystkich państwach członkowskich. $Z$ drugiej, żadnemu normodawcy nie udało się dotąd ukształtować danego modelu stosunków społecznych, na przykład modelu uczciwej konkurencji w postaci hermetycznie zamkniętej regulacji, niepodatnej za zmieniające się zagrożenia i okoliczności zewnętrzne wobec prawa. Taką adaptacyjną i uzupełniającą funkcję wypełniają klauzule generalne oraz różne niedookreślone pojęcia. Nieostrość zwrotów tekstu prawnego (odesłań słusznościowych) jest najprostszym środkiem osiągnięcia elastyczności prawa, ponieważ daje organowi, który je wykonuje pewien luz interpretacji. Pojęcia te zostaną doprecyzowane ostatecznie dopiero w procesie stosowania prawa ${ }^{32}$.

poziomu harmonizacji, [w:] Współczesne wyzwania prawa konsumenckiego, red. B. Gnela, K. Michałowska, Warszawa 2016, s. 16 n.

32 R. Stefanicki, J. Frąckowiak, Prawo konsumenckie - standardy potencjalne i rzeczywiste, w tym gwarancje określone prawem procesowym. Co dalej z regulacja ochrony konsumenta w prawie polskim? (opracowanie podsumowujace wybrane zagadnienia ze spotkań studyjnych), 
Wprowadzanie pojęć tego rodzaju do prawodawstwa ma zatem swoje zalety i jest potrzebne. Problem leży w tym, że wyjaśnianiem tych pojęć zajmą się poszczególne krajowe organy władzy ustawodawczej albo pozostawią to zadanie organom władzy sądowniczej i wykonawczej i ustalenie, co kryje się pod takimi pojęciami, należeć będzie każdorazowo do sądu stosującego prawo i administracji wykonującej ustawy, a to ustalenie w pewnych okolicznościach może nasuwać trudności. Wszystko to powoduje, że pojęcia nieostre stanowią kolejną przeszkodę w dążeniu do jednolitości prawa państw UE. W dyrektywach opartych na metodzie harmonizacji zupełnej powinno się bardzo oszczędnie posługiwać pojęciami niedookreślonymi.

\section{Skutki harmonizacji maksymalnej dyrektyw konsumenckich}

Jednym z najtrudniejszych, ale i najistotniejszych wyzwań stawianych przed ustawodawcą krajowym w procesie transpozycji europejskiego prawa konsumenckiego jest sposób włączenia regulacji unijnych do porządku wewnętrznego. Powinien on gwarantować zachowanie przejrzystości i spójności systemu. Skala trudności zwiększa się jeszcze w odniesieniu do transpozycji dyrektyw maksymalnych ${ }^{33}$. Mimo że związanie systemów krajowych dotyczy poziomu ochrony, a niekoniecznie treści poszczególnych postanowień dyrektywy, można się jednak spodziewać, że w celu spełnienia wymogów metody harmonizacji zupełnej większość państw członkowskich będzie się posługiwać sformułowaniami zaczerpniętymi wprost $\mathrm{z}$ unijnego aktu prawnego ${ }^{34}$, mimo występowania $\mathrm{w}$ rodzimym ustawodawstwie pojęć i instytucji mających już ugruntowane znaczenie ${ }^{35}$.

Od prawidłowego umiejscowienia transponowanej regulacji oraz jej spójnego wkomponowania przez dostosowanie metodologii, siatki pojęciowej i przewodnich zasad, zarówno w kontekście aksjologicznym, jak i formalnym, w znacznym stopniu zależy efektywność (skuteczność) prawa. W Polsce stosuje się mieszaną technikę transpozycji. Część implementowanej materii włącza się do przepisów kodeksowych lub obowiązujących już ustaw, co jest procesem trudniejszym

[w:] Ochrona konsumenta w prawie polskim na tle koncepcji effet utile, red. J. Frąckowiak, R. Stefanicki, Wrocław 2011, s. 24, 25.

33 Ibidem, s. 25.

34 A. Kunkiel-Kryńska, op. cit., s. 292.

35 Na temat problemów z terminologią prawną oraz oficjalnymi thumaczeniami zob. J. Gospodarek, Projektowana dyrektywa turystyczna a przyszłość turystyki w Unii Europejskiej $i$ w Polsce, „Rozprawy Naukowe Akademii Wychowania Fizycznego we Wrocławiu” 2014, nr 46, s. 30 n.; na przykład w dyrektywie zastąpiono pojęcie „konsumenta” terminem ,podróżny” — co autor poddaje uzasadnionej krytyce. 
i rozłożonym w czasie, ale w znacznym stopniu zabezpiecza integrację instytucji i systematyki oraz reżim terminologiczny. Przeważa jednak metoda integracji łatwiejszej, dokonywanej w formie uchwalania odrębnych ustaw. Zwykle rodzi ona największe niebezpieczeństwo rozchwiania krajowego systemu. Może prowadzić do współistnienia w prawie wewnętrznym przepisów sprzecznych oraz nakładających się na siebie, co oczywiście jest nie do przyjęcia i jest niezgodne z zasadami prawidłowej techniki legislacyjnej. Dodatkowo statyczna transpozycja niewpasowana w krajowy porządek prawny przerzuca ciężar wykonywania dyrektywy na organy stosujące prawo ${ }^{36}$.

Dyrektywy zupełne wywierają głęboki wpływ na systemy prawa krajowego, w szczególności na tak zwane systemy skodyfikowane, w których kodeks stanowi kluczowy, trwały i spójny punkt odniesienia. Taka tendencja harmonizacyjna pogłębia i utrwala trudności związane z transpozycją prawa konsumenckiego Unii Europejskiej dokonywaną przez integrację z kodeksem cywilnym. Prawo prywatne cechuje się elastycznością w zabezpieczaniu różnorodnych interesów uczestników obrotu, a dyrektywy oparte na pełnej harmonizacji mogą prowadzić do utraty cechy elastyczności ${ }^{37}$.

Wdrożenie do (spójnego i zupełnego) systemu prawnego postanowień dyrektywy, w której normodawca unijny wycinkowo i zarazem przekrojowo reguluje interesujące go kwestie, musi skutkować „rozchwianiem” systemu. Ochronę konsumenta jako strony słabszej można zaliczyć do współczesnych funkcji prawa cywilnego, ochrona zaś publicznoprawnego interesu UE w postaci ochrony wspólnego rynku (wewnętrznego, jednolitego), nie powinna być funkcją tego prawa ${ }^{38}$.

Harmonizacja zupełna budzi kontrowersje, powoduje rzeczywiste trudności w jej wdrażaniu w poszczególnych krajach. Problemy dotyczą także państw, które mają wdrożyć przepisy, które mogą być mniej ochronne niż obowiązujące u nich poprzednio, co poważnie narusza dotychczasowe prawa przyznane konsumentom na szczeblu krajowym ${ }^{39}$. Oznacza to dla nich równanie w dól, do przyjętego, wspólnego mianownika. Niejednokrotnie oznaczać to będzie konieczność wprowadzenia niższego poziomu ochrony niż uprzednio obowiązujący ${ }^{40}$.

Należałoby też mocniej zaakcentować potrzebę kolizyjnoprawnej ochrony konsumenta. System kilozyjnoprawnej ochrony konsumenta w UE jest jednak skomplikowany i niejednorodny ${ }^{41}$. Prawo właściwe poszczególnym rodzajom umów po-

36 J. Frąckowiak, R. Stefanicki, op. cit., s. 25-26.

37 Zob. A. Kunkiel-Kryńska, op. cit., s. 292.

38 Zob. B. Gnela, op.cit., s. 78-80.

39 F. Morandi, S. Keiler, op. cit., s. 404.

40 P. Cybula słusznie zwraca uwagę na to, że do dyrektywy 2015/2302 wprowadzono (oprócz niewątpliwie prokonsumenckich rozwiązań), wiele instytucji, które w znaczący sposób pogarszają sytuację podróżnego; zob. P. Cybula, Aksjologia zmiany prawa konsumenckiego na przykładzie implementacji w Polsce dyrektywy 2015/2302 w sprawie imprez turystycznych i powiazanych ustug turystycznych, „Folia Turistica” 2018, nr 49, s. 125-149.

41 Zob. M. Jagielska, op. cit., s. 128, 131. 
winno zostać wskazane przez strony umowy zgodnie z przepisami rozporządzenia Parlamentu Europejskiego i Rady Nr 593/2008 z dnia 17 czerwca 2008 roku w sprawie prawa właściwego dla zobowiązań umownych (Rzym I) ${ }^{42}$. Na gruncie tych przepisów możemy mówić o zasadzie kolizyjnoprawnego uprzywilejowania konsumenta ${ }^{43}$. Prawo właściwe umowom konsumenckim określa art. 6 tego rozporządzenia, z wyłączeniami dotyczącymi obszarów wymienionych w art. 6 ust. 4 r.p.w.z.u. Wyłączenia te obejmują między innymi umowy dotyczące imprez turystycznych (art. 6 ust. 4 lit. b r.p.w.z.u. $)^{44}$. Normy prawa prywatnego międzynarodowego nadal łagodzą skutki istniejących różnic między systemami prawnymi, co zresztą uzasadnia pytanie o celowość wyboru materialnoprawnego, a nie kolizyjnoprawnego mechanizmu radzenia sobie z rozbieżnością porządków prawnych ${ }^{45}$.

Trzeba podkreślić, że prawodawca europejski dopuszcza odstępstwa od harmonizacji zupełnej. Swoboda ustawodawcy krajowego polega na możliwości rozciągania postanowień dyrektywy na obszary przez nią nieuregulowane, a także na pewnej dowolności pozostawionej ustawodawcom krajowym i sygnalizowanej w dyrektywie. Może to spowodować chaos, niespójność, niepewność konsumentów co do prawa i dodatkowo pogłębić różnice między systemami prawnymi poszczególnych państw członkowskich.

W kontekście dążenia do jednolitości dodatkowych problemów dostarczają pojęcia niedookreślone. Tylko niekiedy prawodawca unijny przybliża i wyjaśnia ich treść. Pozostawia to newralgiczne i ważkie zadanie ustawodawcom poszczególnych państw członkowskich i krajowym aktom implementacyjnym, jak również organom stosującym prawo i dokonującym jego wykładni, co musi skutkować rozbieżnościami między regulacjami krajowymi i stawia pod dużym znakiem zapytania jednolitość stosowania prawa UE. Nie może się to przyczynić do umacniania wspólnego rynku.

Zastosowanie metody harmonizacji maksymalnej z jednoczesnym zachęcaniem do rozszerzania regulacji na podmioty i przedmioty nią nieobjęte, jak również szerokie posługiwanie się pojęciami niedookreślonymi jest co najmniej niecelowym zabiegiem legislacyjnym. Te dwie koncepcje legislacyjne stoją do siebie w opozycji - należałoby się zdecydować — albo harmonizacja całkowita, albo luz decyzyjny ${ }^{46}$.

42 Dz.U. UEL 177/6 z dnia 4 lipca 2008 roku, dalej: r.p.w.z.u.

43 Zob. M. Pilich, Komentarz do art. 6 Rozporzadzenia Parlamentu Europejskiego i Rady (WE) Nr 593/2008 w sprawie prawa właściwego dla zobowiazań umownych (Rzym I), pkt. 17.1, [w:] Prawo konsumenckie. Komentarz, red. K. Osajda, t. 7, Warszawa 2019, Legalis.

44 W rozporządzeniu Rzym I powołana jest poprzednio obowiązująca dyrektywa z 1990 roku w sprawie zorganizowanych podróży, wakacji, wycieczek. Aktualnie należałoby odnieść te regulacje do obecnie obowiązującej regulacji dyrektywy z 2015 roku.

45 P. Machnikowski, op. cit., s. 17.

46 K. Marak, op. cit., s. 28. 


\section{Zakończenie}

Prawo UE wywiera znaczący wpływ na wewnętrzne prawo prywatne, zarówno w wymiarze konkretnym (doraźnym), kształtuje prawa konsumenta, nadając mu nowe czy modyfikując dotychczas istniejące prawa, jak i wywiera znaczenie szerszy, daleko idący wpływ (systemowy), ingeruje bowiem w tradycyjne zasady prawa cywilnego. Występują znaczne trudności z ,wpasowaniem” nowych regulacji unijnych w system prawa wewnętrznego i osiągnięciem spójności z tym systemem. A jednak nie udaje się osiągnąc pełnej harmonizacji — w pewnych sytuacjach, w kwestiach nieuregulowanych prawem konsumenckim, trzeba zastosować regulację krajową, na przykład krajowe prawo umów. Dyrektywa nie jest też w stanie zharmonizować różnic proceduralnych wynikających z przepisów prawa oraz praktyki sądowej.

Prawem, do którego transponowane są dyrektywy i którego są zobowiązani przestrzegać przedsiębiorcy i konsumenci, jest prawo krajowe. Prawo konsumenckie, choćby ściśle zharmonizowane, stanowi jedynie niewielką część krajowego systemu prawnego 47 .

Widoczne jest, iż mimo ponoszenia wysokich kosztów regulacji nie uda się osiągnąć zakładanych celów i doprowadzić do ujednolicenia przepisów w UE. Dalej możemy mówić jedynie o pewnym zbliżeniu regulacji, a nie ich unifikacji. Wady nadmiernej harmonizacji nie są równoważone jej zaletami ${ }^{48}$. $\mathrm{Z}$ tego punktu widzenia, gdy koszty przewyższają uzyskane efekty, harmonizacja minimalna wydaje się korzystniejsza.

W założeniu harmonizacja maksymalna powinna wydatnie przyczyniać się do urzeczywistniania idei wspólnego rynku, ułatwiać przedsiębiorcom świadczenie usług w sposób transgraniczny i jednocześnie zapewniać wysoki, a zrazem jednolity poziom ochrony konsumentów. Jednakże analiza dyrektyw konsumenckich, w szczególności dyrektywy turystycznej, w kontekście ich transpozycji, prowadzi do wniosku, że harmonizacja maksymalna nie spełni pokładanych w niej oczekiwań — nie doprowadzi do pełnego zbliżenia prawa państw członkowskich w obszarach objętych zakresami dyrektyw. Odrębności będą nadal występować i w dalszym ciągu będą zniechęcać konsumentów do nabywania usług transgranicznych, nie pozwalając w pełni urzeczywistnić idei wspólnego rynku.

Na niewiele zdała się zmiana koncepcji legislacyjnej. Tak jak harmonizacja minimalna nie spełniła pokładanych w niej oczekiwań w postaci zbliżenia prawa państw członkowskich w zakresie ochrony konsumenta, tak harmonizacja maksymalna w pełni nie usunie różnic dzielących poszczególne systemy — nie doprowadzi do unifikacji prawa ochrony konsumentów na obszarze Unii Europejskiej.

Negatywne konsekwencje transpozycji dyrektyw maksymalnych uwidoczniają się natomiast $\mathrm{w}$ postaci znacznej ingerencji $\mathrm{w}$ porządki prawne państw

47 A.P.R. Café, op. cit., s. 349.

48 Ibidem, s. 361. 
członkowskich i mają widoczny, negatywny wpływ na stabilność krajowych systemów prawnych.

Ustawodawca krajowy niejednokrotnie w sposób pobieżny dokonuje transpozycji dyrektyw, nie podejmując wzmożonego i koniecznego, zwłaszcza w wypadku dyrektyw maksymalnych, wysiłku zintegrowania transponowanych regulacji z porządkiem wewnętrznym państwa. Skutki tego rodzaju zaniechań spadają następnie na organy stosujące prawo. W pewnym stopniu ustawodawcę usprawiedliwia jednak okoliczność, że w niektórych sytuacjach nie sposób znaleźć dobrych rozwiązań legislacyjnych. Wynika to z założeń samej dyrektywy maksymalnej i braku konsekwencji prawodawcy unijnego, który dąży do jedności regulacji we wszystkich państwach członkowskich a jednocześnie dopuszcza wyjątki od tychże regulacji. Nie może wówczas być mowy o jednolitości prawa w całej Unii.

\section{Bibliografia}

Café A.P.R., Package Travel Directive: Contractual parties and level of harmonization, [w:] The New Package Travel Directive, red. V. Franceschelli, F. Morandi, C. Torres, Lisboa 2017.

Cieśliński A., Wspólnotowe prawo gospodarcze, Warszawa 2003.

Cybula P., Aksjologia zmiany prawa konsumenckiego na przyktadzie implementacji $w$ Polsce dyrektywy 2015/2302 w sprawie imprez turystycznych i powiazanych ustug turystycznych, „Folia Turistica" 2018, nr 49, s. 125-149.

Gnela B., Umowa konsumencka w polskim prawie cywilnym i prywatnym międzynarodowym, Warszawa 2013.

Gospodarek J., Implementacja nowej dyrektywy turystycznej z 2015 r. do systemu prawa polskiego, [w:] Prawo konsumenckie w Polsce oraz innych państwach UE. Zagadnienia wybrane, red. B. Gnela, E. Słogocka-Krupa, M. Szaraniec, A. Viglianisi Ferraro, Warszawa 2019.

Gospodarek J., Projektowana dyrektywa turystyczna a przyszłość turystyki w Unii Europejskiej i w Polsce, „Rozprawy Naukowe Akademii Wychowania Fizycznego we Wrocławiu” 2014, nr 46.

Grzegorczyk F., Jednolity rynek europejski jako determinant rozwoju prawa konsumenckiego w Unii Europejskiej, KPP 19, 2010, z. 4.

Jagielska M., Ewolucja ochrony konsumenta w prawie kolizyjnym UE w zakresie zobowiązań umownych, Warszawa 2010.

Kępiński M., Harmonizacja maksymalna - nowe wyznanie dla ustawodawcy, [w:] Aktualne tendencje w prawie konsumenckim, red. R. Stefanicki, Wrocław 2010.

Kunkiel-Kryńska A., Metody harmonizacji prawa konsumenckiego w Unii Europejskiej i ich wpływ na procesy implementacyjne w państwach członkowskich, Warszawa 2013.

Łętowska E., Interpretacja a subsumpcja zwrotów niedookreślonych i nieostrych, PiP 2011, nr 7-8.

Machnikowski P., Harmonizacja maksymalna jako metoda zbliżania prawa zobowiazań w UE na przyktadzie odpowiedzialności za produkt, „Studia Prawa Prywatnego” 2017, nr 35.

Maliszewska-Nienartowicz J., Ewolucja ochrony konsumenta w europejskim prawie wspólnotowym, Torun 2004.

Marak K., Harmonizacja maksymalna projektowanej dyrektywy turystycznej i możliwe odstepstwa od tak wyznaczonego poziomu harmonizacji, [w:] Współczesne wyzwania prawa konsumenckiego, red. B. Gnela, K. Michałowska, Warszawa 2016. 
Morandi F., Keiler S., The directive on package travel and linked travel arrangements: The traveller protection in a full harmonisation approach, [w:] The New Package Travel Directive, red. V. Franceschelli, F. Morandi, C. Torres, Lisboa 2017.

Pilich M., Komentarz do art. 6 Rozporzadzenia Parlamentu Europejskiego i Rady (WE) Nr 593/2008 w sprawie prawa właściwego dla zobowiazań umownych (Rzym I), pkt. 17.1, [w:] Prawo konsumenckie. Komentarz, red. K. Osajda, t. 7, Warszawa 2019, Legalis.

Stefanicki R., Koncepcja petnej harmonizacji prawa ochrony konsumenta (na przyktadzie dyrektywy o nieuczciwych praktykach handlowych), PiP 2011, z. 6.

Stefanicki R., Tendencje zmian w europejskiej strategii ochrony konsumenta, „Kwartalnik Prawa Prywatnego" 18, 2008, z. 3.

Stefanicki R., Frąckowiak J., Prawo konsumenckie — standardy potencjalne i rzeczywiste, w tym gwarancje określone prawem procesowym. Co dalej z regulacja ochrony konsumenta w prawie polskim? (opracowanie podsumowujace wybrane zagadnienia ze spotkań studyjnych), [w:] Ochrona konsumenta w prawie polskim na tle koncepcji effet utile, red. J. Frąckowiak, R. Stefanicki, Wrocław 2011.

Zieliński M., Wykładnia prawa. Zasady. Reguły. Wskazówki, Warszawa 2002.

\section{Transposition of maximum consumer directives in the example of the 2015 Travel Directive in Polish legislation}

Summary

Consumer directives adopted in large numbers during the 1980s and 1990s were based on the method of minimum harmonisation. However, this did not bring the expected results in terms of satisfactory convergence of Member States' legal systems and at the beginning of the 21st century the EU legislator abandoned minimum harmonisation in favour of full or maximum harmonisation. Tourist services were covered by the 1990 Directive on package holidays, package tours, and package travel, which was based on the lowest common denominator. Now it has been replaced by the 2015 Directive on package travel and associated tourism services, which follows the trend of the maximum directives.

The article analyses and evaluates the effectiveness of the full harmonisation method as a way of achieving the objectives and guidelines of consumer directives based on the example of the Travel Directive of 2015. It is intended that maximum harmonisation should contribute significantly to the completion of the single market, facilitate the cross-border provision of services by traders, and at the same time ensure a high and uniform level of consumer protection. However, analysis of consumer directives in the context of their transposition leads to the conclusion that maximum harmonisation is unlikely to meet expectations. It does not appear that it will lead to full convergence of legislation in the areas covered by the Directives. Distinctness will continue to exist and will continue to discourage consumers from cross-border services. On the other hand, the negative consequences of the transposition of the maximum directives are manifested by considerable interference with the legal orders of Member States and may have a negative impact on the stability of national legal systems.

Keywords: consumer protection, maximum harmonisation, travel directive, package travel contract, consumer directives. 